\title{
Mathematics examinations of days past
}

\author{
Sandro Caparrini
}

Published online: 21 May 2014

(C) Centro P.RI.ST.EM, Università Commerciale Luigi Bocconi 2014

\begin{abstract}
Annotations to an excerpt from the English translation by Rev. Baden Powell of the "History of My Youth" by the physicist and astronomer François Arago (1786-1853) regarding mathematics examinations in the early 1800 s.
\end{abstract}

Keywords History of teaching - Ecole Polytechnique . 19th-century mathematics

What were the examinations in mathematics like at the beginning of the 1800s? And how were Lagrange's texts used by students in that period? We can have an idea thanks to an exceptional witness, François Arago (1786-1853), an important physicist, astronomer and French statesman. As a physicist, in 1809 he carried out an experiment from which he discovered the constancy of the speed of light, exactly one century before the birth of Special Relativity. As an astronomer, he wrote the best treatise of all time for non-specialists. As a statesman, he was the head of French government twice, in stormy periods.

In his last years, Arago wrote a brief "Histoire de ma jeunesse", or "History of My Youth" [1, 2], in which he tells of his career and his encounters with the great French scientists in the early years of the nineteenth century. It was a time in which a scientist might live an adventurous life: during his first scientific mission in Spain, Arago had to defend himself against brigands and was captured by pirates. In all likelihood Jules Verne invented much less that is believed. Here I have added some footnotes to the

S. Caparrini $(\bowtie)$

Dipartimento di Matematica, Università di Torino, Via Carlo Alberto, 10, 10123 Turin, Italy

e-mail: sandro.caparrini@unito.it nineteenth-century translation of the tract by Rev. Baden Powell, published in 1859, to clarify a few details, but perhaps the reader would prefer to read without interruptions this very enjoyable gallery of eccentric types.

\section{An excerpt from "History of My Youth" as translated by Rev. Baden Powell}

Walking one day on the ramparts of the town, ${ }^{1}$ I saw an officer of engineers who was directing the execution of the repairs. This officer, $M$. Cressac, was very young; I had the hardihood to approach him, and to ask him how he had succeeded in so soon wearing an epaulette. "I come from the Polytechnic School," he answered. "What school is that?" "It is a school which one enters by an examination". "Is much expected of the candidates?" "You will see it in the programme which the Government send every year to the departmental administration; you will find it moreover in the numbers of the journals of the school which are in the library of the central school".

I ran at once to the library, and there, for the first time, I read the programme of the knowledge required in the candidates.

From this moment I abandoned the classes of the central school, where I was taught to admire Corneille, Racine, La Fontaine, Molière, and attended only the mathematical course. This course was entrusted to a retired ecclesiastic, the Abbé Verdier, a very respectable man, but whose knowledge went no further than the elementary course of

\footnotetext{
${ }^{1}$ At the time this excerpt describes, François Arago, son of a local administrator, was living in Estagel (in southern France) near the border with Spain. At school he did not particularly distinguish himself. This part of the story begins in 1800; Arago was 14 years old.
} 
La Caille. ${ }^{2}$ I saw at a glance that M. Verdier's lessons would not be sufficient to secure my admission to the Polytechnic School; I therefore decided on studying by myself the newest works, which I sent for from Paris. These were the works of Legendre, ${ }^{3}$ Lacroix, ${ }^{4}$ and Garnier. ${ }^{5}$ In going through these works I often met with difficulties which exceeded my powers; happily, strange though it be, there was a proprietor at Estagel, M. Raynal, who made the study of higher mathematics his recreation. It was in his kitchen, whilst giving orders to numerous domestics for the labours of the next day, that M. Raynal read with advantage the "Hydraulic Architecture" of M. Prony, ${ }^{6}$ the "Mécanique Analytique" ${ }^{7}$ and the "Mécanique Céleste". ${ }^{8}$ This excellent man often gave me useful advice; but I must say that I found my real master in the cover of M. Garnier's "Treatise on Algebra". This cover consisted of a printed leaf, on the outside of which blue paper was pasted. The reading of the page not covered made me desirous to know what the blue paper hid from me. I took off this paper carefully, having first damped it, and was able to read underneath it the advice given by d'Alembert to a young man who communicated to him the difficulties which he met with in his studies: "Go on, sir, go on, and conviction will come to you".

This gave me a gleam of light; instead of persisting in attempts to comprehend at first sight the propositions before me, I admitted their truth provisionally; I went on further, and was quite surprised, on the morrow, that I comprehended perfectly what overnight appeared to me to be encompassed with thick clouds.

\footnotetext{
${ }^{2}$ Nicolas-Louis de La Caille (1713-1762), Leçons élémentaires de mathématiques; ou Élémens d'algèbre et de géométrie (Paris, Guérin, 1747). There are various editions of this text.

3 Adrien-Marie Legendre (1752-1833), Éléments de géométrie, avec des notes (Paris, Didot, 1794). There are various editions of this classic text.

${ }^{4}$ Silvestre-François Lacroix (1765-1843), Élémens d'algèbre, à l'usage de l'École centrale des Quatre-Nations (Paris, Duprat, 1799). Lacroix wrote various texts for didactics, all excellent, but his treatise on algebra is the one that would have been studied by a young man who wanted to enter the École Polytechnique.

5 Jean-Guillaume Garnier (1766-1840), Élémens d'algèbre, a l'usage des aspirans a l'Ecole Polytechnique (Paris, Courcier, 1803).

${ }^{6}$ Gaspard Clair François Marie Riche de Prony (1755-1839), Nouvelle architecture hydraulique, contenant l'art d'élever l'eau au moyen de différentes machines, de construire dans ce fluide, de le diriger, et généralement de l'appliquer, de diverses manieres, aux besoins de la société (Paris, Didot, 1790-96). In spite of the title emphasising engineering, the first part is a general treatise on mechanics.

7 Spelling notwithstanding, Arago is referring to the first edition: Méchanique analitique (Paris, 1788).

${ }^{8}$ Pierre-Simon de Laplace (1749-1827), Traité de mécanique céleste, 5 vols. (Paris, 1798-1824). In 1800, Mr Raynal would have had at his disposition only the first two volumes.
}

I thus made myself master, in a year and a half, of all the subjects contained in the programme for admission, and I went to Montpellier to undergo the examination. I was then 16 years of age. M. Monge, junior, ${ }^{9}$ the examiner, was detained at Toulouse by indisposition, and wrote to the candidates assembled at Montpellier that he would examine them in Paris. I was myself too unwell to undertake so long a journey, and I returned to Perpignan.

There I listened for a moment to the solicitations of my family, who pressed me to renounce the prospects which the Polytechnic School opened. But my taste for mathematical studies soon carried the day; I increased my library with Euler's "Introduction à l'Analyse Infinitésimale", ${ }^{10}$ with the "Résolution des Equations Numériques", ${ }^{11}$ with Lagrange's "Théorie des Fonctions Analytiques" 12 and "Mécanique Analytique", and finally with Laplace's "Mécanique Céleste". I gave myself up with great ardour to the study of these books. From the journal of the Polytechnic School containing such investigations as those of M. Poisson on Elimination, ${ }^{13}$ I imagined that all the pupils were as much advanced as this geometer, and that it would be necessary to rise to his height to succeed.

From this moment, I prepared myself for the artillery service-the aim of my ambition; and as I had heard that an officer ought to understand music, fencing, and dancing, I devoted the first hours of each day to the cultivation of these accomplishments.

The rest of the time I was seen walking in the moats of the citadel of Perpignan, seeking by more or less forced transitions to pass from one question to another, so as to be sure of being able to show the examiner how far my studies had been carried.

At last the moment of examination arrived, and I went to Toulouse in company with a candidate who had studied at the public college. It was the first time that pupils from Perpignan had appeared at the competition. My intimidated comrade $^{14}$ was completely discomfited. When I repaired

\footnotetext{
${ }^{9}$ This is the younger brother of the mathematician Gaspard Monge.

10 The Introductio in analysin infinitorum is of 1748 . Arago probably used the French translation by Labey: Introduction à l'analyse infinitésimale (1795-96).

${ }^{11}$ Traité de la résolution des équations numériques de tous les degrés (Paris, 1797).

12 Théorie des fonctions analytiques: contenant les principes du calcul différentiel, dégagés de toute consideration d'infiniment petits ou d'évanouissans, de limites ou de fluxions, et réduits à l'analyse algébrique des quantités finies (Paris, 1797).

${ }^{13}$ Siméon-Denis Poisson, "Mémoire sur l'élimination dans les équations algébriques", Journal de l'École Polytechnique, 11ème cahier, t. 4, pp. 199-203 (1801-1802).

${ }^{14}$ In the original, camarade. The term of a military flavour is fitting because at the aim at beginning the École Polytechnique was principally to train officers of the military engineering corps.
} 
after him to the board, a very singular conversation took place between M. Monge (the examiner) and me.

"If you are going to answer like your comrade, it is useless for me to question you".

"Sir, my comrade knows much more than he has shown; I hope I shall be more fortunate than he; but what you have just said to me might well intimidate me and deprive me of all my powers".

"Timidity is always the excuse of the ignorant; it is to save you from the shame of a defeat that I make you the proposal of not examining you".

"I know of no greater shame than that which you now inflict upon me. Will you be so good as to question me? it is your duty".

"You carry yourself very high, sir! We shall see presently whether this be a legitimate pride".

"Proceed, sir; I wait for you".

M. Monge then put to me a geometrical question, which I answered in such a way as to diminish his prejudices. From this he passed on to a question in algebra, to the resolution of a numerical equation. I had the work of Lagrange $^{15}$ at my fingers' ends; I analyzed all the known methods, pointing out their advantages and defects; Newton's method, the method of recurring series, ${ }^{16}$ the method of depression, ${ }^{17}$ the method of continued fractions ${ }^{18}$-all were passed in review; the answer had lasted an entire hour. Monge, brought over now to feelings of great kindness, said to me, "I could, from this moment, consider the examination at an end. I will, however, for my own pleasure, ask you two more questions. What are the relations of a curved line to the straight line which is tangent to it?" I looked upon this question as a particular case of the theory of osculations which I had studied in Legrange's [sic] "Fonctions Analytiques". "Finally", said the examiner to me, "how do you determine the tension of the various cords of which a funicular machine is composed?" I treated this problem according to the method expounded in the "Mècanique Analytique". It was clear that Lagrange had supplied all the resources of my examination.

I had been $2 \mathrm{~h}$ and a quarter at the board. M. Monge, going from one extreme to the other, got up, came and embraced me, and solemnly declared that I should occupy the first place on his list. Shall I confess it? During the examination of my comrade I had heard the Toulousian

\footnotetext{
15 He refers to the Traité de la résolution des équations numériques de tous les degrés.

16 By Daniel Bernoulli, published in 1728.

17 Rev. Powell's translation "method of depression" of the French méthode des cascades refers to the "method cascades" introduced by Michel Rolle in his Traité d'algèbre of 1690.

18 By Lagrange, published in 1774.
}

candidates uttering not very favourable sarcasms on the pupils from Perpignan; and it was principally for the sake of reparation to my native town that M. Monge's behaviour and declaration transported me with joy.

Having entered the Polytechnic School, at the end of 1803 , I was placed in the excessively boisterous brigade of the Gascons and Britons. I should have much liked to study thoroughly physics and chemistry, of which I did not even know the first rudiments; but the behaviour of my companions rarely left me any time for it. As for analysis, I had already, before entering the Polytechnic School, learnt much for than was required for leaving it.

I have just related the strange remarks which $\mathrm{M}$. Monge, junior, addressed to me at Toulouse in commencing my examination for admission. Something analogous occurred at the opening of my examination in mathematics for passing from one division of the school to another. The examiner, this time, was the illustrious geometer Legendre, of whom, a few years after, I had the honour of becoming the colleague and friend.

I entered his study at the moment when $\mathrm{Mr}$. $\mathrm{T}$ - who was to undergo his examination before me, having fainted away, was being carried out in the arms of two servants. ${ }^{19} \mathrm{I}$ thought that this circumstance would have moved and softened M. Legendre; but it had no such effect. "What is your name", he said to me sharply. "Arago", I answered. "You are not French then?" "If I was not French I should not be before you; for I have never heard of any one being admitted into the school unless his nationality had not been proved". "I maintain that he is not French whose name is Arago". "I maintain, on my side, that I am French, and a very good Frenchman too, however strange my name may appear to you". "Very well; we will not discuss the point further; go to the board".

I had scarcely taken up the chalk, when M. Legendre, returning to the first subject of his preoccupations, said to me: "You were born in one of the departments recently united to France?" "No, sir; I was born in the department of the Eastern Pyrenees, at the foot of the Pyrenees". "Oh! why did you not tell that at once? all is now explained. You are of Spanish origin, are you not?" "Possibly; but in my humble family there are no authentic documents preserved which could enable me to trace back the civil position of my ancestors; each one there is the child of his own deeds. I declare to you again that I am French, and that ought to be sufficient for you".

The vivacity of this last answer had not disposed $\mathrm{M}$. Legendre in my favour. I saw this very soon; for, having put a question to me which required the use of double integrals, he stopped me, saying: "The method which you

\footnotetext{
${ }^{19}$ In the original, garçons de salle; these were assistants in the lecture halls.
} 
are following was not given to you by the professor. Whence did you get it?" "From one of your papers." "Why did you choose it? was it to bribe me?" "No; nothing was further from my thoughts. I only adopted it because it appeared to me to be preferable". "If you are unable to explain to me the reasons for your preference, I declare to you that you shall receive a bad mark, at least as to character".

I then entered upon the details which established, as I thought, that the method of double integrals was in all points more clear and more rational than that which Lacroix had expounded to us in the amphitheatre. From this moment Legendre appeared to me to be satisfied, and to relent.

Afterwards he asked me to determine the centre of gravity of a spherical sector. "The question is easy", I said to him. "Very well; since you find it easy, I will complicate it: instead of supposing the density constant, I will suppose that it varies from the centre to the surface according to a determined function". I got through this calculation very happily; and from this moment I had entirely gained the favour of the examiner. Indeed, on my retiring, he addressed to me these words, which, coming from him, appeared to my comrades as a very favourable augury for my chance of promotion: "I see that you have employed your time well; go on in the same way the second year, and we shall part very good friends" [2, pp. 5-10].

\section{Postscriptum: a final reference to Lagrange}

In 1809, at only 23 years old, Arago was elected a member of the Paris Academy of Sciences. His competitor, Poisson, obtained only four votes; Arago no fewer than 47. Laplace, who had supported Poisson, had opposed Arago's election in all ways. It is at this point in Arago's recollections that Lagrange makes a brief appearance. The fact that a pure mathematician had supported an experimental physicist like Arago against the mathematician Poisson, Laplace's favourite, might either provide a clue to an academic rivalry, or indicate a certain interest on Lagrange's part in experiments:

M. Laplace, without denying the importance and utility of these labours ${ }^{20}$ and these researches, saw in them nothing more than indications of promise; $\mathrm{M}$. Lagrange then said to him explicitly:

"Even you, M. de La place, when you entered the Academy, had done nothing brilliant; you only gave promise. Your grand discoveries did not come till afterwards".

Lagrange was the only man in Europe who could with authority address such an observation to him $[2$, p. 81].

\section{References}

1. Arago, F.: Histoire de ma jeunesse. Oeuvres complètes, vol. I, pp. 1-102. Paris (1853)

2. Arago, F.: The history of my youth, Rev. Baden Powell, trans. In: Biographies of Distinguished Scientific Men, vol. I, pp. 1-90. Ticknor and Fields, Boston (1859)

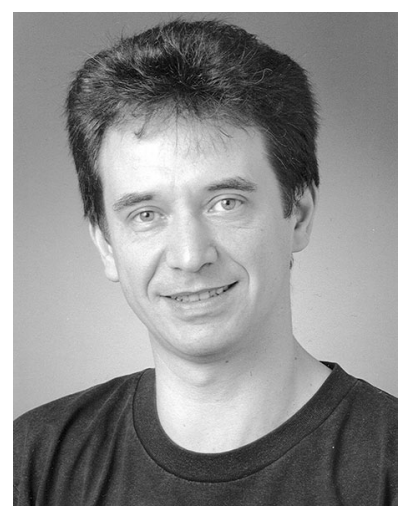

Sandro Caparrini holds degrees in Physics and in Mathematics and a Ph.D. in Mathematics from the University of Turin. His research interests are mainly focused on the history of the interaction between mathematics and mechanics from 1750 onward. He has held postdoctoral positions at the Dibner Institute (Harvard and MIT), at the Cohn Institute (Tel Aviv), at the Institute for the History and Philosophy of Science and Technology (Toronto) and at the Dept. of Mathematics of the University of Lille (France). In 2004 he was awarded the Slade Prize from the British Society for the History of Science.

${ }_{20}$ This is in reference to the first research works by Arago. 